\title{
Non-EU migrant doctors in Ireland: applying a typology of health worker migration
}

\author{
Niamh Humphries ${ }^{1 *}$, Sara McAleese ${ }^{1}$, Ella Tyrrell ${ }^{2}$, Steve Thomas $^{2}$, Charles Normand ${ }^{2}$, Ruairi Brugha ${ }^{2}$ \\ From Health Services Research: Evidence-based practice \\ London, UK. 1-3 July 2014
}

\section{Background}

Research on health worker migration in the Irish context has previously sought to categorize migrant health workers by country or region of training (e.g. non-EU nurses or doctors), by migration channel or mechanism (e.g. actively recruited nurses). This paper applies a recently developed typology of health worker migration [1], to the experiences of non-EU migrant doctors in Ireland and considers the value of a typology of health worker migration to human resource management internationally.

\section{Materials and methods}

The paper draws on quantitative $(\mathrm{N}=37)$ and qualitative $(\mathrm{N}=337)$ data collected from non-EU migrant doctors in Ireland between 2011 and 2013.

\section{Results}

While non-EU migrant doctors can be categorized according to the typology [1], in the Irish context, a cross-cutting theme of frustration emerged from doctors in almost all categories. In addition to 'career oriented migrants' expressing frustration at poor career progression, were 'returners' who could not return home because of their limited career progression in Ireland and 'livelihood migrants' frustrated with weak career progression.

\section{Conclusions}

Employing a typology of health worker migration can facilitate a more comprehensive understanding of the migrant medical workforce, a necessary prerequisite for the development of useful policy tools [2]. However, our findings suggest that migrant health workers cannot be divorced from the health system context in which they work in the destination country, and perhaps this should be incorporated into the typology.

${ }^{1}$ Department of Epidemiology, RCSI, Dublin, Ireland

Full list of author information is available at the end of the article

\section{Acknowledgements}

Thanks to the Health Research Board for funding the Doctor Migration

Project (RCSI \& TCD) HRA_HSR/2010/18.

\section{Authors' details}

${ }^{1}$ Department of Epidemiology, RCSI, Dublin, Ireland. ${ }^{2}$ Centre for Health Policy and Management, Trinity College Dublin, Ireland.

Published: 7 July 2014

\section{References}

1. Glinos I, Buchan J: Health Professionals crossing the European Union's internal and external borders: A typology of health professional mobility and migration. In Health Professional Mobility in a Changing Europe - New dynamics, mobile individuals and diverse responses. WHO \& European Observatory on Health Systems and Policies;Buchan J, et al. 2014:.

2. Glinos I, et al: Health Professional Mobility and Health Systems in Europe: Conclusions from the Case Studies. In Health Professional Mobility and Health Systems Evidence from 17 European Countries. World Health Organisation \& European Observatory on Health Systems and Policies; Wismar W, et al. 2011:

doi:10.1186/1472-6963-14-S2-O21

Cite this article as: Humphries et al:: Non-EU migrant doctors in Ireland: applying a typology of health worker migration. BMC Health Services Research 2014 14(Suppl 2):O21.
Submit your next manuscript to BioMed Central and take full advantage of:

- Convenient online submission

- Thorough peer review

- No space constraints or color figure charges

- Immediate publication on acceptance

- Inclusion in PubMed, CAS, Scopus and Google Scholar

- Research which is freely available for redistribution
() Biomed Central 